\title{
PENATAKELOLAAN KAWASAN HUTAN RAWAN KONFLIK MELALUI PENDEKATAN METODOLOGI SISTEM LUNAK : KASUS HUTAN PENELITIAN BENAKAT, SUMATERA SELATAN (Governing the close-to-conflict state forestland through soft systems methodology: The case of benakat research forest, South Sumatra)
}

\author{
Oleh / by : \\ Edwin Martin $^{1)}$, Bondan Winarno ${ }^{1)}$, Herry Purnomo, Nurheni Wijayanto ${ }^{2)}$
}

\begin{abstract}
There are plenty of Indonesian forest areas in the condition of unmanaged and neglected so that perceived as prone to conflict. It could happened due to government indecisiveness in to dealing with other stakeholder preferences on appropriate land-uses. One known approach to systems design that focuses on explicating different perspectives is Soft Systems Methodology (SSM), which has been used widely and succesfully in many problem situations. The main objective of research is to develop understanding on divergence of opinion of stakeholder toward achieving desirable and feasible change, by application of SSM. Research was situated on one of neglected management-block within Benakat Research Forest at South Sumatra, namely "Agroforestry Block". It's concluded that intervention phase of SSM which driven by reflective facilitation could enhance social learning among contrary actors, so that offered new pathway to the future of Agroforestry Block. This phase has not significantly change the attitude of involvedparticipantsyet.
\end{abstract}

Key words: Conflict, Governance, research forest management, Soft Systems Methodology

\begin{abstract}
ABSTRAK
Banyak kawasan hutan Indonesia berada dalam kondisi tidak terkelola dan terabaikan sehingga dianggap sebagai kawasan konflik. Hal tersebut terjadi karena ketidaktegasan pemerintah berkaitan dengan keinginan pemangku kepentingan terhadap penggunaan sumber daya. Salah satu pendekatan yang dikenal baik yang memfokuskan pada penjelasan sudut pandang yang berbeda ialah Soft System Methode (SSM), yang digunakan luas dan berhasil dalam banyak situasi masalah yang rumit. Tujuan utama dari penelitian ini adalah untuk mengembangkan pemahaman opini stakeholder yang berbeda (terpencar) terhadap perubahan yang diinginkan dan memungkinkan, dengan menggunakan SSM. Penelitian dilaksanakan di salah satu blok pengelolaan yang terabaikan di Hutan Penelitian Benakat di Sumatera Selatan, yang disebut "Agroforestry Block". Disimpulkan bahwa tahap intervensi dari SSM yang dikendalikan dengan fasilitas reflektif/umpan balik dapat meningkatkan pembelajaran sosial diantara pelaku-pelaku yang bertentangan, sehingga
\end{abstract}

\footnotetext{
Balai Penelitian Kehutanan Palembang; Fasilitator dalam penelitian ini. e-mail:abinuha1976@yahoo.co.id

${ }^{2)}$ Fakultas Kehutanan dan Sekolah Pascasarjana Institut Pertanian Bogor (IPB)
} 
menawarkan cara baru terhadap pengelolaan masa depan blok agroforestry. Tahap ini belum secara signifikan mengubah perilaku partisipan yang terlibat

Kata kunci: konflik, pemerintah, manajemen penelitian hutan, Soft System Methode

\section{PENDAHULUAN}

\section{A. Latar belakang}

Indonesia saat ini memiliki 50 taman nasional dan 32 hutan penelitian sebagai unit manajemen kawasan hutan yang dikelola langsung oleh pemerintah. Fakta menunjukkan bahwa tidak sedikit dari kawasan atau bagian kawasan tersebut berada dalam kondisi "tidak terkelola". Ini terlihat dari berubahnya tata guna lahan menjadi bukan hutan, maraknya pencurian kayu, dan kebakaran hutan berulang. Keadaan ini cenderung dibiarkan dan tidak tertangani jika berada dalam situasi yang dianggap rawan konflik (Kadir, 2005; Suharti et al., 2005; Wiati, 2005; Abbas, 2005).

Peter Checkland pada awal dekade 1980-an mengemas konsep penelitian aksi dan berpikir sistem (lunak) menjadi Soft Systems Methodology (Metodologi Sistem Lunak-MSL) (Mingers, 2000; Chapman, 2004). Metodologi ini dikembangkan untuk menangani masalahmasalah manajemen yang muncul dari sistem aktivitas manusia, misalnya konflik.

Metodologi Sistem Lunak merupakan kerangka kerja (framework) pemecahan masalah yang dirancang secara khusus untuk situasi dimana hakikat masalah sulit untuk didefinisikan (Sinn, 1998). Esensinya adalah membangun model sistem melalui pemahaman dan pemaknaan secara mendalam situasi masalah sesuai fenomena yang dihadapi (Williams, 2005). Metodologi ini bertujuan untuk memperbaiki masalah sosial yang dihadapi dengan melibatkan secara aktif aktor-aktor yang berkepentingan melalui sebuah siklus pembelajaran yang idealnya tidak pernah berhenti (Chapman, 2004). MSL berparadigma interpretive (Sinn, 1998; Mingers, 2000; Jackson, 2001; Luckett et al., 2001), sehingga teknik penerapannya di lapangan sangat tergantung dengan konteks penelitian, situasi permasalahan, perilaku aktor-aktor, dan kemampuan pengguna.

Beragamnya bidang pemanfaatan Metodologi Sistem Lunak menunjukkan handalnya pendekatan ini dalam membantu pemecahan masalah yang berkaitan dengan kompleksitas interaksi manusia. Dalam bidang manajemen saja, Holwell (2000) mencatat 250 referensi seperti makalah jurnal, makalah seminar, dan buku teks yang menggunakan pemikiran Metodologi Sistem Lunak. MSL juga telah diaplikasikan dalam bidang manajemen sumberdaya alam dan lingkungan Dalam bidang ini, Nidumolu et al. (2006) berhasil memanfaatkan pendekatan MSL untuk menyusun program perencanaan tata guna lahan di India. Bunch (2002) mampu membuat rekomendasi pengelolaan lingkungan bantaran sungai di India. Haklay (1999) menganalisis dampak lingkungan pembangunan perumahan di Israel. Namun, MSL masih jarang digunakan oleh peneliti dan praktisi di Indonesia (Eriyatno, 2003; Eriyatno dan Sofyar, 2007).

Informasi keberhasilan aplikasi MSL di berbagai bidang dapat menjadi pijakan untuk mengadaptasikan pendekatan berorientasi perubahan ini bagi upaya mengkreasi tatakelola kawasan-kawasan hutan "tidak terkelola" di Indonesia. Tatakelola (governance) adalah aturan yang mengatur hubungan-hubungan antar aktor (yang secara potensial memungkinkan terjadinya konflik) agar terhindar dari konflik atau menghilangkan gangguan terhadap 
peluang-peluang pencapaian hasil yang saling menguntungkan (Williamson, 1996). Namun proses-proses multipihak, seperti penerapan MSL ini memiliki konsekuensi kesiapan dana dan waktu jika difasilitasi oleh pihak yang dianggap netral. Padahal, keterbatasan dana merupakan situasi masalah yang umum dihadapi institusi-institusi pemerintah. Penelitian ini akan menjawab pertanyaan "Apakah aplikasi MSL melalui fasilitasi reflektif, sebuah caracara fasilitasi yang dilakukan oleh orang atau kelompok orang yang terlibat dalam situasi masalah itu sendiri, dapat menghasilkan langkah penatakelolaan bagi kawasan hutan yang dianggap rawan konflik dan mengubah sikap aktor-aktor yang terlibat dalam proses penelitian". Penelitian mengambil contoh kasus "tidak terkelolanya" Blok Agroforestri Hutan Penelitian Benakat, di Sumatera Selatan.

\section{B. Tujuan Penelitian}

Penelitian bertujuan untuk : (1) mengetahui apakah proses penelitian berbasis MSL melalui fasilitasi reflektif mampu mengubah suasana konflik menjadi media pembelajaran bersama sehingga menghasilkan langkah penatakelolaan bagi Blok Agroforestri Hutan Penelitian Benakat; (2) mengetahui apakah proses penelitian berbasis MSL dapat mengubah sikap para pihak terhadap tata guna lahan di Blok Agroforestri.

\section{METODE PENELITIAN}

\section{A. Konteks Penelitian}

Penelitian ini difokuskan pada penggunaan Metodologi Sistem Lunak (MSL) sebagai upaya penatakelolaan kawasan hutan "tidak terkelola" yang disebabkan oleh anggapan adanya kerawanan konflik. Penelitian mengambil contoh kasus Blok Agroforestri Hutan Penelitian Benakat di Sumatera Selatan. Hutan Penelitian Benakat ditetapkan Menteri Kehutanan melalui SK. No. 111 tanggal 24 April 2004 sebagai Kawasan Hutan dengan Tujuan Khusus (KHDTK) Penelitian dan Pengembangan.

Blok Agroforestri Hutan Penelitian Benakat yang terletak di Kabupaten Muara Enim Sumatera Selatan adalah salah satu contoh kawasan hutan yang dikelola langsung oleh pemerintah (dalam hal ini Balai Penelitian Kehutanan-"BPK"- Palembang) tetapi "tidak terkelola”. Kawasan ini pada mulanya diperuntukkan sebagai tapak untuk kegiatan penelitian dan pengembangan aspek Agroforestri. Kini, sebagian besar lahannya telah dimanfaatkan oleh masyarakat Desa Benakat Minyak dan Semangus menjadi perkebunan karet dan pemukiman. Tekanan dan preferensi tata guna lahan masyarakat tersebut dianggap sebagai masalah sosial yang rumit untuk ditangani karena dikhawatirkan akan memicu konflik terbuka.

\section{B. Rancangan Aplikasi Metodologi Sistem Lunak}

Proses utama penelitian menggunakan modus operandi penelitian aksi (McNiff, 1992) yang diarahkan untuk mendukung berlangsungnya tahapan Metodologi Sistem Lunak, melalui fasilitasi reflektif (Groot dan Maarleveld, 2000). Tahapan Metodologi Sistem Lunak yang dijalankan yaitu (Simonsen, 1994; Williams, 2005): (1) Memasuki situasi bermasalah; (2) Mengekspresikan situasi masalah; (3) Memformulasikan definisi akar sistem dari situasi masalah; (4) Membangun model konseptual dari definisi akar sistem; (5) Membandingkan 
model konseptual dengan dunia nyata; (6) Menentukan langkah-langkah perubahan yang diinginkan; (7) Melakukan aksi untuk memperbaiki situasi masalah (Gambar 1). Penelitian dikonsentrasikan pada tahap 1 hingga 6 , sementara pelaksanaan tahap 7 oleh para pihak merupakan indikator tercapainya tujuan pertama penelitian. Luckett et al., (2001) menyebut proses seperti ini sebagai fase intervensi.

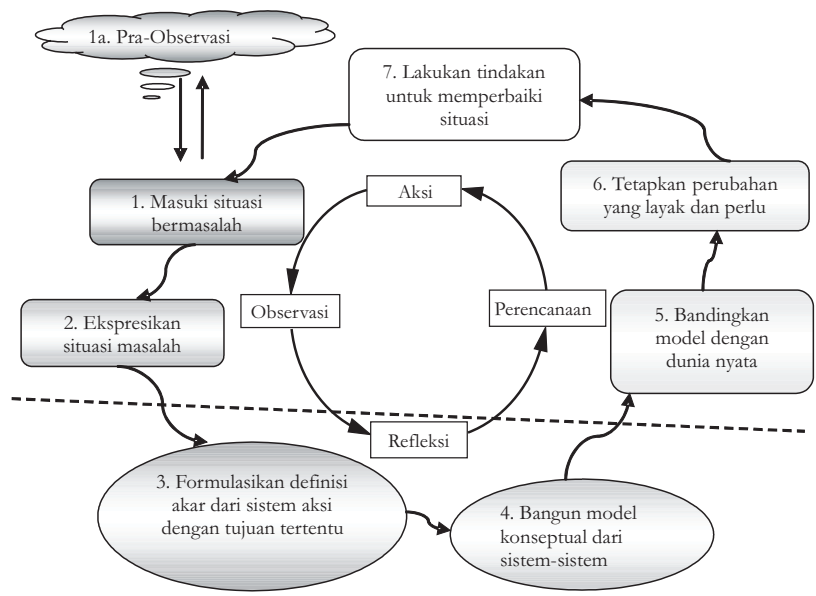

Gambar1(Figure 1). Tahapan penelitian dalam kerangka kerja Metodologi Sistem Lunak (Research steps in the frame work of soft system Methodology)

Intervensi diawali dengan aktivitas penentuan stakeholder dan pendefinisian isu (sebagaimana disarankan oleh Adelson, 1999; Ramírez dan Fernández, 2004; Martin dan Borges, 2007) untuk memasuki situasi sistem sosial kompleks. Peneliti menyebut tahapan awal ini sebagai pra-observasi.

\section{Observasi: Pendefinisian isu dan penentuan aktor (tahap 1 dalam MSL)}

Tahap observasi dimulai pada minggu ketiga Bulan Juli 2007. Tahap ini berkaitan dengan upaya untuk mendorong para pihak bersedia bertemu dalam satu forum agar dialog antarpihak dapat dilakukan. Wawancara kelompok fokus (focus group interviews-FGIs) (Brits dan Plessis, 2007) yang dilakukan pada setiap kelompok para pihak merupakan alat utama dalam tahap ini. Para pihak utama adalah mereka yang berasal dari BPK Palembang, pemanfaat dari Desa Benakat Minyak dan Semangus.

Forum FGIs mengajukan pertanyaan yang sama kepada setiap kelompok pihak, yaitu: (1) Apa yang anda cita-citakan, harapkan, impikan, atau inginkan dari kawasan Blok Agroforestri; (2) Apa yang (dapat) menjadi penghambat pencapaian cita-cita, impian dan keinginan anda itu. Setiap kelompok pihak merumuskan "harapan dan masalah" kelompok mereka terhadap keberadaan Blok Agroforestri. Kegiatan tersebut difasilitasi oleh kelompok peneliti dengan meyakinkan kepada setiap kelompok bahwa aspirasi yang mereka susun akan disampaikan secara utuh oleh wakil kelompoknya dalam suatu pertemuan antarkelompok pihak.

Selain merumuskan "harapan dan masalah", setiap kelompok pihak juga diminta untuk menunjuk aktor yang akan menjadi wakil kelompoknya dalam proses penelitian berikutnya, berdasarkan kriteria "who really count" yang dibuat oleh Mitchell et al. (1998) dalam Magness (2007), yaitu kekuatan (power), kepentingan (urgency), dan keabsahan (legitimacy). 
Seorang aktor diharapkan paling tidak memiliki dua dari tiga kriteria tersebut. Selain itu, mereka berhak mengusulkan individu atau kelompok di luar para pihak utama yang dianggap memenuhi kriteria "who really count". Aktor yang mewakili para pihak utama dan non utama ini merupakan partisipan dalam proses penelitian. Tercatat sebanyak 18 orang aktor yang berperan aktif sejak dari proses observasi hingga implementasi rencana aksi.

Pemahaman situasi masalah dan pendefinisian isu dilengkapi dengan pengumpulan informasi mengenai sejarah dan status pemanfaatan areal Blok Agroforestri, melalui pengumpulan data sekunder, wawancara rumah tangga dan observasi lapangan. Kegiatan wawancara rumah tangga dibantu oleh masyarakat setempat untuk memudahkan penentuan responden dan proses wawancara. Observasi dilaksanakan oleh peneliti dengan cara tinggal di Desa Benakat Minyak dan Semangus selama beberapa waktu.

\section{Refleksi dan Pemantauan implementasi rencana aksi (tahap 2 sampai 7)}

Hasil tahap observasi dijadikan pijakan untuk memulai tahap refleksi dan penyusunan rencana aksi, melalui forum lokakarya (search conference). Lokakarya dilaksanakan selama 2 hari, tanggal 14 sampai dengan 15 November 2007 bertempat di Wisma Mawar Pertamina Pendopo, Kecamatan Talang Ubi Muara Enim. Proses utama dalam lokakarya meliputi ekspresi situasi masalah, refleksi melalui analisis sistem dan pemodelan, dan penyusunan rencana aksi. Proses tersebut merupakan adaptasi tahapan Metodologi Sistem Lunak.

Lokakarya merupakan proses berlanjut dari tahapan pra-observasi, dimana peneliti berperan sebagai fasilitator reflektif (Groot dan Maarleveld, 2000). Ini memungkinkan terjadinya komunikasi efektif antar aktor untuk saling menerima rancangan proses penelitian. Proses kegiatan dalam dua hari lokakarya merupakan adaptasi tahapan Metodologi Sistem Lunak (Tabel 1).

Tabel 1 (Table 1). Tata waktu proses kegiatan lokakarya (Time schedule of workshop process)

\begin{tabular}{lc}
\hline \multicolumn{1}{c}{ Kegiatan } & Waktu \\
Pembukaan, Doa, Perkenalan, Kontrak Belajar & Hari 1 \\
Pemahaman situasi masalah (Tahap 1 dan 2) & Hari 1 \\
Identifikasi solusi atas isu-definisi akar sistem (Tahap 3) & Hari 1 \\
Analisis sistem pengelolaan Blok Agroforestri (Tahap 4) & Hari 1 \\
Diskusi perbedaan antara model konseptual dengan faktual (Tahap 5) & Hari 2 \\
Perubahan apa yang kita inginkan (Tahap 6) & Hari 2 \\
Skenario aktivitas untuk mencapai perubahan (Tahap 6) & Hari 2 \\
Peran masing-masing aktor (pihak) dalam skenario (Tahap 6) & Hari 2 \\
Penutupan & Hari 2 \\
\hline
\end{tabular}

Implementasi aksi untuk memperbaiki situasi masalah merupakan tahap akhir dari Metodologi Sistem Lunak (tahap 7). Pada tahap ini, peneliti tidak terlibat secara langsung dalam aksi yang dilaksanakan para pihak karena fokus penelitian berada pada fase intervensi. Pada bulan ke-6 setelah ditetapkannya rencana aksi, peneliti mendokumentasikan apakah terjadi langkah-langkah pengelolaan bagi Blok Agroforestri. Pelaksanaan kegiatan yang sesuai dengan rencana yang dibuat dalam lokakarya menjadi indikator tercapainya tujuan penelitian. 


\section{Analisis Perubahan Sikap Partisipan Penelitian}

Zubair dan Garforth (2006) menilai sikap seseorang dari dua komponen yaitu kekuatan keyakinan (belief strength) dan evaluasi manfaat (outcome evaluation). Dalam konteks penelitian ini kekuatan keyakinan diukur melalui tiga skala Likert, yaitu setuju (3), ragu-ragu (2), dan tidak setuju (1); sementara evaluasi manfaat dilihat dari ukuran penting (3), ragu-ragu (2), dan tidak penting (1).

Nilai peubah sikap yang terdiri dari sub peubah kekuatan keyakinan dan evaluasi manfaat merupakan respon aktor-aktor sebagai wakil para pihak terhadap pernyataanpenyataan keyakinan dan manfaat model tata guna lahan Blok Agroforestri. Peubah sikap dari para pihak utama diukur pada saat setelah mereka menunjuk aktor untuk mengikuti lokakarya; sementara aktor dari para pihak non utama menyatakan sikap setelah mereka memahami situasi masalah (langkah 1 dan 2), dan pada saat pascalokakarya. Signifikansi perubahan sikap para pihak dianalisis melalui tes McNemar (Siegel, 1992).

Untuk menguji signifikansi setiap perubahan yang diobservasi dengan metode ini, dibentuk suatu tabel frekuensi yang berbentuk segi empat, ABCD. Dalam tes McNemar peneliti hanya berkepentingan pada sel A yang menunjukkan perubahan sikap dari positif menjadi negatif dan $\mathrm{D}$ yang menunjukkan perubahan sikap dari negatif menjadi positif. Nilai A dan D kemudian dianalisis signifikansi perbedaannya melalui analisis chi-square apabila nilai frekuensi harapan besar, yaitu $1 / 2(A+D)>5$, atau melalui uji binomium jika nilai frekuensi harapan kecil, yakni $1 \frac{1}{2}(\mathrm{~A}+\mathrm{D})<5$.

\section{HASIL DAN PEMBAHASAN}

\section{A. Intervensi melalui aplikasi Metodologi Sistem Lunak}

\section{Situasi lapangan dan Status pemanfaatan Blok Agroforestri}

Dusun Benakat Minyak berada di dalam Kawasan Hutan Produksi BenakatSemangus, dimana kawasan tersebut telah dibebani hak pengusahaan hutan tanaman industri oleh PT. Musi Hutan Persada (MHP) sejak tahun 1990-an. Pada era orde baru warga Benakat Minyak hanya boleh memanfaatkan kawasan hutan untuk usaha pertanian tanaman semusim dalam luasan terbatas. Pada tahun 2002, pemerintah daerah meningkatkan status dusun tersebut menjadi desa definitif. Peningkatan status ini dianggap warga sebagai legitimasi untuk menguasai areal kawasan hutan di sekitarnya, termasuk lahan Blok Agroforestri dan menggunakannya menjadi perkebunan karet. Lahan dan perambahan kawasan hutan adalah isu sensitif di Desa Benakat Minyak. Ini merupakan pemicu konflik terbuka antara masyarakat dengan P'T. MHP.

Desa Semangus merupakan desa yang sejak lama menggunakan lahan Blok Agroforestri sebagai pemukiman dan areal usahatani. Masyarakat yang bermukiman di kawasan ini sebagian besar adalah peladang berpindah yang diminta oleh Departemen Kehutanan pada tahun 1980-an untuk menjadi peserta program penelitian agroforestri. Sejak "proyek" penelitian agroforestri berakhir tahun 1994, masyarakat menggantungkan sumber nafkah keluarganya dari pekerjaan sebagai buruh PT. MHP. Sementara itu, usahatani tanaman semusim dianggap tidak mampu memenuhi kebutuhan rumah tangga.

Masyarakat Desa Benakat Minyak dan Semangus menganggap usaha penanaman karet di areal Blok Agroforestri (Tabel 2) sebagai upaya untuk memperbaiki nasib dan keluar 
dari garis kemiskinan. Harga getah karet yang dianggap cukup memuaskan dalam tiga tahun terakhir memicu makin tingginya keinginan masyarakat untuk memiliki kebun karet, terutama dari jenis karet unggul. Ini mendorong penguatan perjuangan masyarakat untuk memperoleh pengakuan atas lahan kawasan hutan yang telah mereka tanami pohon karet. Kepemilikan kebun karet dianggap sebagai cara terbaik untuk merubah masa depan keluarga. Mereka siap melakukan konfrontasi dengan pihak manapun demi mempertahankan kebun karetnya ini.

Tabel 2 (Table 2). Deskripsi penguasaan kebun karet di Blok Agroforestri Hutan Penelitian Benakat. (Description of ......... rubber estate in agroforest block of Benakat research forest)

\begin{tabular}{lcc}
\hline \multirow{2}{*}{ Peubah } & \multicolumn{2}{c}{ Desa asal pemanfaat } \\
\cline { 2 - 3 } & Benakat Minyak & Semangus \\
\hline Jumlah pemanfaat yang menanam karet & 27 orang $(\mathrm{kk})$ & 26 orang $(\mathrm{kk})$ \\
Luas total kebun karet & $108,5 \mathrm{ha}$ & $55 \mathrm{ha}$ \\
Rata-rata luas penguasaan setiap kk & $4,02 \mathrm{ha}$ & $2.12 \mathrm{ha}$ \\
Luas maksimal kebun karet kk & $16 \mathrm{ha}$ & $14,5 \mathrm{ha}$ \\
Luas minimal kebun karet kk & $1 \mathrm{ha}$ & $1 \mathrm{ha}$ \\
Modus luas kebun karet kk & $2 \mathrm{ha}$ & $1 \mathrm{ha}$ \\
Jumlah kk yang menguasai $>5$ ha & $8 \mathrm{kk}$ & $1 \mathrm{kk}$ \\
\hline
\end{tabular}

Sumber (Source): Data primer hasil wawancara rumah tangga, diolah.

\section{Ekspresi situasi masalah}

Hasil observasi disampaikan oleh masing-masing pihak dalam tahap awal forum lokakarya. Ketiga pihak utama menyampaikan hasil rumusan tentang "harapan dan masalah" terhadap Blok Agroforestri, sementara peneliti mempresentasikan "status pengelolaan Blok Agroforestri dulu dan kini". Ini memungkinkan semua aktor, termasuk aktor di luar para pihak utama menerima informasi yang sama sehingga dapat memahami dan mendiskusikan situasi masalah yang ada secara lebih menyeluruh.

Manifestasi konflik mulai terasa pada saat aktor-aktor mengekspresikan pandangan masing-masing terhadap keberadaan Blok Agroforestri serta situasi kekiniannya. Aktoraktor dari masyarakat berpandangan bahwa tanaman karet di Blok Agroforestri harus mereka pertahankan apapun caranya, karena dianggap sebagai sumber penghidupan dan kesejahteraan. Sementara, aktor-aktor dari BPK Palembang berpendapat bahwa kebun karet masyarakat menjadi penghalang kegiatan mereka.

Pihak-pihak utama merasa bahwa sikap dan tindakan yang dilakukan oleh kelompoknya terhadap Blok Agroforestri adalah sesuatu yang baik dan benar, serta didukung oleh alasan yang dianggap masuk akal. Situasi ini membuat suasana diskusi cukup tegang (groan zone). Masing-masing pihak berusaha mempertahankan pendapatnya. Keinginan masing-masing pihak ini ditawarkan menjadi isu dalam lokakarya. Isu tersebut adalah: (1) Blok Agroforestri menjadi wadah kegiatan penelitian dan pengembangan agroforestri yang berkelanjutan, (2) Blok Agroforestri menjadi areal yang produktif sehingga menyejahterakan masyarakat, dan (3) Masyarakat memperoleh ketenangan dan kenyamanan dalam berusahatani di Blok Agroforestri. 


\section{Memformulasikan definisi akar sistem dari situasi masalah}

Isu yang telah disepakati untuk dibahas lebih lanjut merupakan harapan situasi masa depan yang diinginkan masing-masing pihak. Situasi sekarang masih berlawanan dengan harapan tersebut. Ini berarti ada sesuatu yang harus diubah agar harapan dapat menjadi kenyataan.

Hasil diskusi menyebutkan bahwa masyarakat akan mencapai ketenangan dan kenyamanan dalam berusahatani apabila aspek aturan dan hukum dapat berubah (Tabel 3). Demikian pula dengan penyelenggaraan penelitian sebagai posisi pihak pengelola, hanya akan terlaksana apabila program penelitiannya berbeda dari yang pernah ada. Meningkatnya kesejahteraan masyarakat sebagai visi bersama para pihak dianggap akan terwujud apabila aspek pola usahatani diperbaiki.

Tabel 3 (Table 3). Hasil analisis elemen yang diinginkan untuk berubah guna mencapai situasi masa depan Blok Agroforestri yang diidamkan para pihak

\begin{tabular}{ccc}
\hline Input (SAAT INI) & $\begin{array}{c}\text { Transformasi (Sistem yang harus } \\
\text { berubah) }\end{array}$ & Output (HARAPAN) \\
\hline $\begin{array}{c}\text { Masyarakat yang berusahatani di } \\
\text { Blok Agroforestri tidak merasa } \\
\text { tenang dan nyaman }\end{array}$ & Aturan dan hukum & $\begin{array}{c}\text { Masyarakat merasa tenang dan } \\
\text { nyaman dalam berusahatani }\end{array}$ \\
\hline $\begin{array}{c}\text { Blok Agroforestri tanpa kegiatan } \\
\text { Litbang }\end{array}$ & $\begin{array}{c}\text { Program } \\
\text { Penelitian }\end{array}$ & $\begin{array}{c}\text { Fungsi penelitian dapat } \\
\text { dilaksanakan di Blok Agroforestri } \\
\text { kapanpun dan dimanapun }\end{array}$ \\
\hline $\begin{array}{c}\text { Masyarakat kurang modal dan } \\
\text { pengetahuan dalam berusahatani } \\
\text { produktif }\end{array}$ & Pola Usahatani & $\begin{array}{c}\text { Masyarakat menjadi petani } \\
\text { produktif dan kesejahteraan } \\
\text { meningkat }\end{array}$ \\
\hline
\end{tabular}

Elemen-elemen transformasi yang disepakati para pihak disadari sebagai keinginan yang hendak dicapai pada masa depan dan belum terjadi saat ini. Aktor-aktor membuat beberapa ukuran (indikator) keberhasilan proses transformasi masa depan untuk setiap elemen (sub-sistem). Indikator tersebut yaitu: Aturan dan Hukum, akan dinilai dari: (1) kualitas ketenangan dan kenyamanan dalam berusahatani dan (2) kualitas hubungan masyarakat dengan pengelola (pemerintah). Program Penelitian, akan dinilai dari: (1) jumlah kegiatan litbang, (2) tingkat adopsi hasil penelitian, (3) realisasi rencana penelitian. Pola Usahatani, akan dinilai dari: (1) pendapatan masyarakat, (2) produktivitas Lahan, dan (3) jumlah pemanfaat lahan.

\section{Membangun model konseptual dari definisi akar sistem}

Solusi atas isu pengelolaan Blok Agroforestri dirasakan masih bersifat abstrak, belum operasional. Oleh karena itu, fasilitator meminta kepada aktor-aktor untuk menuliskan pendapatnya pada kertas metaplan tentang aktivitas yang seharusnya dilakukan oleh para pihak agar ketiga elemen dapat berubah.

Ide-ide aktivitas yang dibuat partisipan lokakarya didiskusikan kelogisannya dalam mencapai indikator perubahan melalui teknik $\mathrm{PQR}^{3}$. Aktor-aktor kemudian dibagi ke dalam tiga kelompok (komisi) sesuai jumlah sub sistem (elemen) yang diidentifikasi sebelumnya. Setiap komisi beranggotakan semua unsur para pihak. Komisi bertugas menyusun hubungan saling bergantung antaraktivitas dan indikator keberhasilannya.

\footnotetext{
${ }^{3)}$ Memperbaiki P (tranformasi) melalui Q (aktivitas) agar tercapai R (tujuan sistem)
} 
Diskusi penyusunan model konseptual bagi masa depan pengelolaan Blok Agroforestri ini dapat berjalan dengan baik. Fasilitator berperan pasiv. Aktor-aktor sangat antusias dalam merancang sistem yang berpengaruh bagi masa depan kehidupan dan pelaksanaan tugas para pihak. Pengambilan keputusan lebih mudah terjadi karena materi diskusi tidak lagi membahas aktivitas masa lalu dan saatini.

Aktor-aktor berhasil merancang tiga model konseptual untuk masing-masing subsistem perubahan. Semua aktor dapat memahami struktur aktivitas dalam setiap model karena merupakan sistem sepakat.

Subsistem hukum dan aturan bertujuan untuk mencapai kualitas kenyamanan masyarakat dalam berusahatani dan kualitas hubungan antara masyarakat dengan pengelola Blok Agroforestri (Gambar 2). Inventarisasi potensi lahan secara rinci dianggap sebagai awal yang harus ditempuh agar aktivitas lain dapat berjalan. Ini dianggap perlu dilakukan karena tata guna kawasan Blok Agroforestri telah jauh berbeda dengan rancangan lapangan penelitian Agroforestri yang dulu dibuat oleh Proyek ATA-186.

Inventarisasi lahan secara rinci akan menghasilkan peta tata guna lahan faktual yang sesuai dengan kondisi tutupan lahan yang ada. Selain itu, jumlah pemanfaat dan luasan areal yang diusahakannya akan dapat diketahui secara pasti. Peta tata guna lahan faktual adalah dasar penyusunan proses perijinan status lahan (proses pengaturan hak-hak penguasaan) sehingga mencapai kejelasan status lahan. Penyuluhan hukum diperlukan untuk menguatkan proses pengaturan hak-hak penguasaan Blok Agroforestri oleh masyarakat. Masyarakat akan berinisiatif membentuk kelompok pemanfaat apabila telah cukup jelas siapa saja yang menjadi pemanfaat tetap dan status penguasaan lahannya.

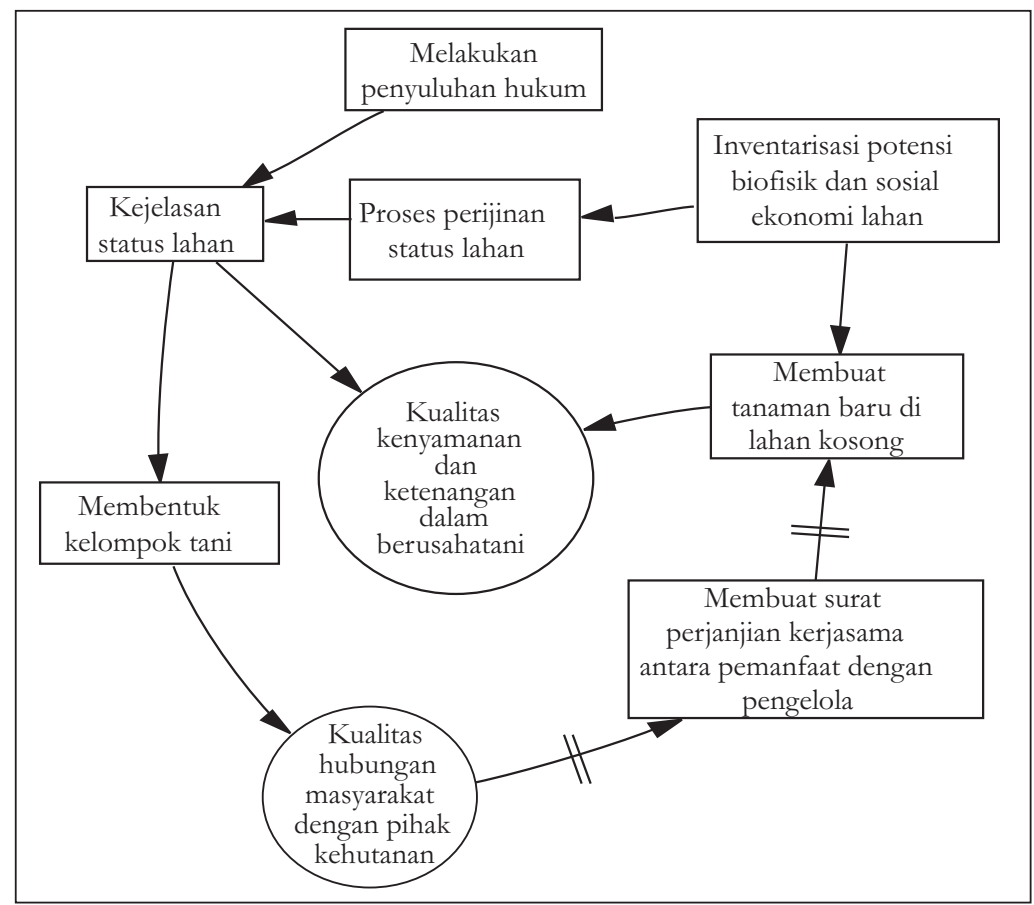

Gambar 2 (Figure 2). Model konseptual untuk perubahan "hukum dan aturan" dalam pengelolaan Blok Agroforestri KHDTK Benakat. 
Pembentukan kelompok pemanfaat Blok Agroforestri akan memudahkan komunikasi antara masyarakat dengan pengelola. Namun demikian, surat perjanjian kerjasama antara pemanfaat dan pengelola hanya akan dibuat apabila kedua belah pihak mengevaluasi terlebih dahulu kualitas hubungan mereka. Prasyarat juga dibuat untuk aktivitas "pembuatan tanaman baru di lahan kosong", dimana hanya akan dilakukan di seluruh areal (termasuk lahan yang telah atau pernah menjadi kebun karet) apabila substansi surat perjanjian kerjasama dapat diterima kedua pihak. Kualitas kenyamanan dan ketenangan dalam berusahatani dianggap akan tercapai apabila telah ada kejelasan status lahan dan pelaksanaan pembuatan petak ujicoba "penanaman tanaman baru" (tanaman hanya dilakukan di areal kosong yang belum dimanfaatkan masyarakat.

Rancangan model konseptual "Program Penelitian" merupakan ekspresi kritik dan aspirasi aktor-aktor dari masyarakat atas program penelitian yang selama ini dilakukan pihak pengelola (Gambar 3). Elemen sentral dalam subsistem ini adalah program penelitian partisipatif, sebagai gabungan dari 3 (tiga) aktivitas yaitu inventarisasi potensi biofisik dan sosial ekonomi Blok Agroforestri, pemilahan penelitian yang sesuai dengan sosial ekonomi dan budaya setempat dan didukung oleh peran peneliti. Peran peneliti hanya dapat didorong apabila pimpinannya memprioritaskan kegiatan litbang untuk wilayah ini. Ini dianggap penting mengingat selama ini peneliti umumnya tidak berminat menempatkan site kegiatan litbang-nya di Blok Agroforestri yang dianggap rawan konflik dan vandalisme.

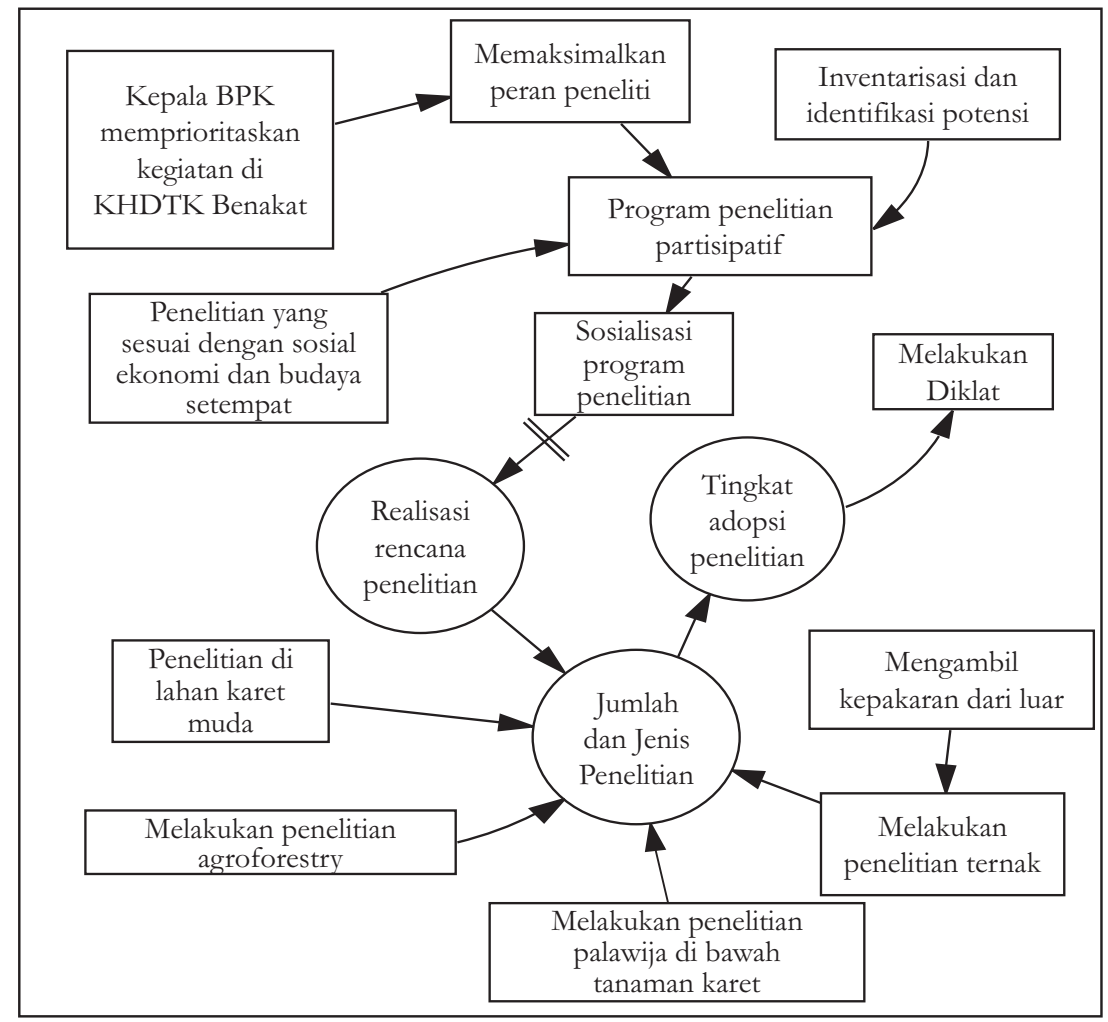

Gambar 3 (Figure 3). Model konseptual untuk perubahan "Program Penelitian" di Blok Agroforestri KHDTK Benakat. 
Tanda prasyarat (delay mark) pada arah panah yang menuju realisasi rencana penelitian dalam model konseptual diartikan bahwa penelitian hanya dapat terealisasi apabila dalam sosialisasinya dapat diterima masyarakat. Ini dilakukan karena selama ini beberapa penelitian memang disosialisasikan kepada mereka namun tidak ada dialog menyangkut aspek kemanfaatan penelitian (pragmatisme). Beberapa penelitian sebelumnya, baik yang dirancang oleh peneliti dari Indonesia maupun Jepang dianggap hanya untuk memenuhi hasrat peneliti tanpa melihat manfaat praktis bagi masyarakat.

Model konseptual "Program Penelitian" memasukkan penelitian-penelitian yang dianggap memiliki kemanfaatan praktis sebagai elemen yang dapat menghasilkan pencapaian indikator jumlah dan jenis penelitian. Lebih jauh, apabila jumlah dan jenis penelitian dianggap tercapai maka akan dilakukan evaluasi tingkat adopsinya dalam masyarakat. Hasil-hasil penelitian yang teradopsi dengan baik akan dijadikan bahan rujukan bagi aktivitas pendidikan dan latihan, tidak hanya bagi masyarakat setempat tetapi juga bagi masyarakat lainnya di luar KHDTK Benakat.

Subsistem usahatani dirancang oleh aktor-aktor secara lebih sederhana dan relatif tanpa perdebatan (Gambar 4). Model konseptual ini menganggap bahwa penghasilan masyarakat akan berubah apabila produktivitas lahan juga berubah. Menurut partisipan lokakarya, produktivitas lahan dipengaruhi oleh kondisi jalan, adanya modal usaha melalui pinjaman lunak, dan diterapkannya pola usahatani terkini.

Modal usaha dalam bentuk pinjaman lunak dikelola oleh koperasi, namun pendirian koperasi hanya bisa dilakukan apabila jumlah pemanfaat lahan Blok Agroforestri tidak lebih sedikit dari sekarang. Prasyarat pendirian koperasi tersebut muncul dari kekhawatiran aktoraktor, terutama dari aparat pemerintah daerah yang melihat kecenderungan penguasaan areal oleh beberapa orang saja.

Aktivitas menerapkan pola usahatani terkini akan meningkatkan produktivitas lahan dan memengaruhi jumlah petani yang mendapat manfaat langsung dari Blok Agroforestri. Penerapan teknologi budidaya lahan yang intensif dianggap sebagai pisau bermata dua; produktivitas per satuan lahan (kebun) meningkat sehingga menurunkan keinginan satu keluarga untuk menguasai kebun yang luas, atau sebaliknya teknologi hanya bisa diterapkan oleh beberapa orang saja yang memiliki cukup modal. Oleh karena itu, aktivitas menerapkan pola usahatani terkini dipengaruhi oleh hasil pendidikan dan latihan (diklat) dan adopsi hasilhasil penelitian, dua aktivitas yang terdapat pula dalam subsistem "Program Penelitian". Ini berarti ada keterkaitan antarsubsistem.

Keterkaitan tiga subsistem pengelolaan Blok Agroforestri muncul sendiri dalam diskusi penyempurnaan model konseptual (dalam pleno). Inventarisasi potensi biofisik dan sosial ekonomi adalah awal menuju perubahan subsistem "Hukum dan Aturan" dan subsistem "Program Penelitian", sementara adopsi hasil penelitian sebagai indikator dalam subsistem "Program Penelitian" merupakan salah satu elemen penting dalam subsistem "Pola Usahatani". Jika digabungkan maka ketiga subsistem tersebut akan membentuk kesatuan model konseptual sistem pengelolaan Blok Agroforestri.

Model konseptual sistem pengelolaan Blok Agroforestri disusun oleh beragam aktivitas yang saling berurutan dan terkait secara logis. Model konseptual sistem aktivitas ini diuji kemampuannya dalam menelusuri kemungkinan pencapaian indikator harapan masa depan, melalui simulasi. Ini dimungkinkan karena struktur aktivitas dalam model sistem merupakan hasil kesepakatan dan konsensus sebagai proses pemetaan kognitif orang-orang. 


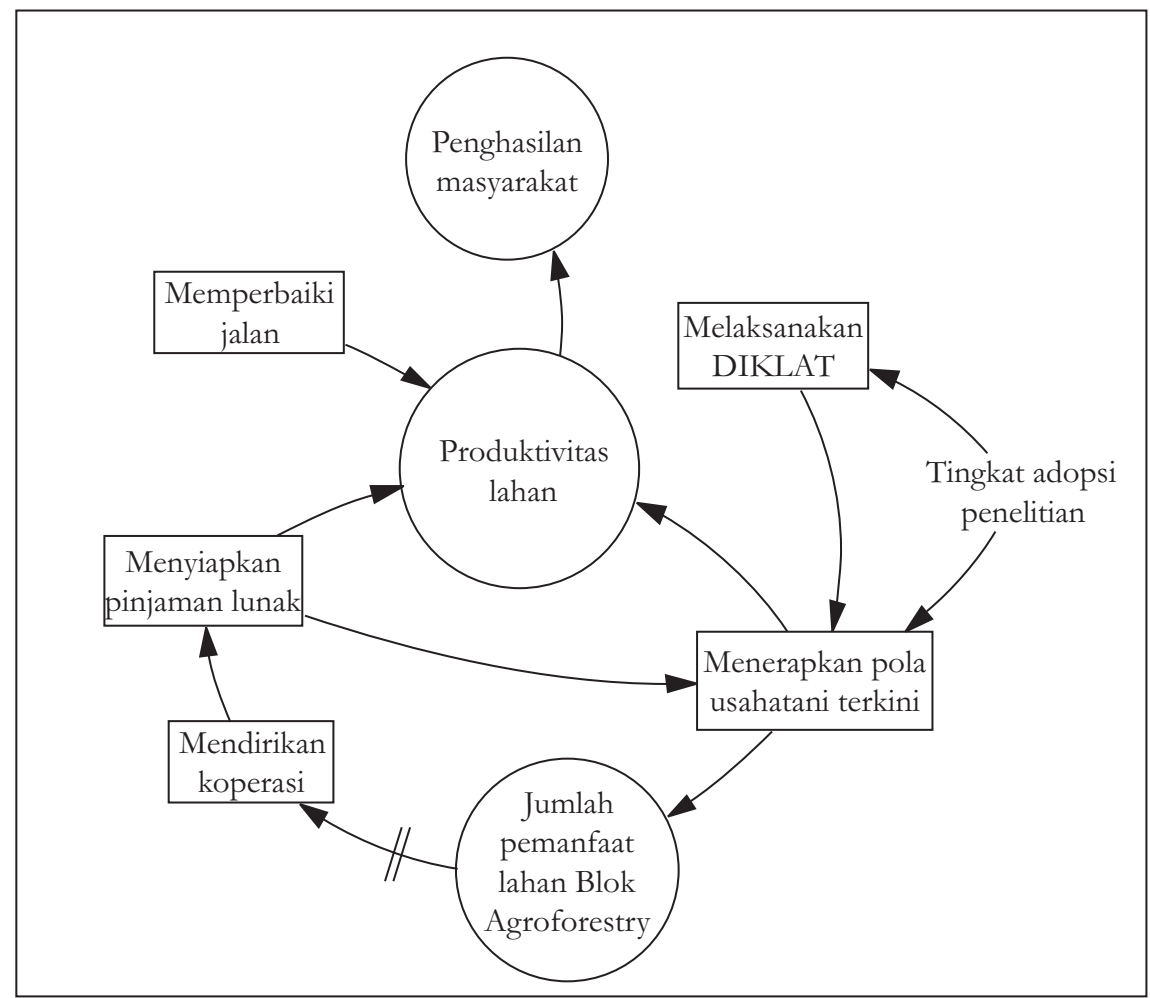

Gambar 4 (Figure 4). Model konseptual untuk perubahan "Pola Usahatani” masyarakat di Blok Agroforestri KHDTK Benakat.

Simulasi berhasil memproyeksikan ukuran indikator-indikator tujuan sistem pada masa depan dalam dua skenario, yakni mengeksekusi model konseptual (posisi "keinginan kita") atau tidak menjalankannya sama sekali (posisi "perkiraan"). Tampilan hasil simulasi tersebut berupa grafis proyeksi posisi indikator-indikator dalam tiga masa, dulu (1980-a), kini (2007), dan masa depan (2020). Fasilitator menyiapkan grafis, sementara aktor-aktor mendiskusikan mengenai dimana posisi indikator seharusnya ditempatkan.

Hasil simulasi, misalnya untuk indikator penghasilan masyarakat, menunjukkan bahwa penghasilan masyarakat saat ini lebih tinggi dibanding era 1980-an, dimana pada masa itu akses mereka terhadap kawasan hutan masih terbatas. Saat ini kebun karet yang berada di Blok Agroforestri mulai menghasilkan getah sehingga diperkirakan akan makin produktif dalam tahun-tahun mendatang. Ini berarti, tanpa harus menjalankan aktivitas dalam model, penghasilan masyarakat akan tetap mengalami peningkatan (Gambar 5).

\section{Membandingkan model konseptual dengan dunia nyata}

Hasil evaluasi terhadap beragam aktivitas dalam model konseptual masing-masing sub sistem menunjukkan bahwa hampir seluruh aktivitas tidak/belum terjadi di dunia nyata. Pengabaian tindakan manajemen atas Blok Agroforestri dirasakan sebagai penyebab tidak berjalannya fungsi kawasan ini. Oleh karena itu, aktor-aktor merancang tindakan inisiatif untuk setiap aktivitas dalam model konseptual. 

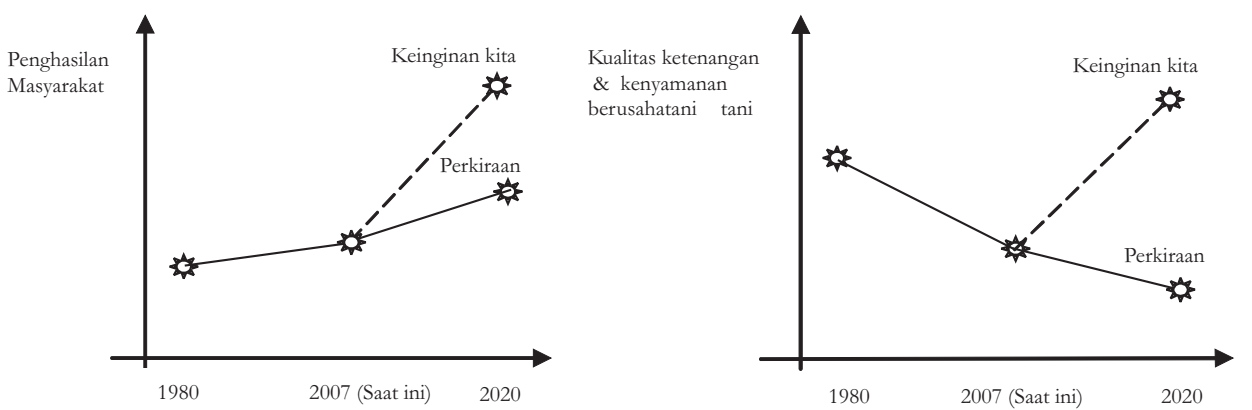

Gambar 5 (Figure 5). Proyeksi dua indikator submodel aturan dan hukum pada masa depan

Tindakan inisiatif yang dibuat berdasarkan komparasi model konseptual dengan situasi yang terjadi di dunia nyata merupakan upaya mewujudkan beragam aktivitas harapan menjadi kenyataan. Ini berarti muncul keinginan aktor-aktor untuk menjadikan model konseptual sebagai rujukan tindakan nyata, dengan cara menurunkan taraf abstraksi setiap aktivitas dalam model menjadi lebih bersifat teknis.

\section{Menentukan langkah-langkah perubahan yang diinginkan}

Perbandingan antara model konseptual dengan kondisi faktual menguatkan keinginan aktor-aktor untuk membuat prioritas bagi aktivitas yang dapat ditempuh dalam jangka waktu secepatnya. Prioritas aktivitas dalam model konseptual yang bisa dilakukan para pihak untuk segera diwujudkan menjadi aksi nyata ditetapkan sebagai berikut: (1) Melakukan inventarisasi lahan, (2) Membentuk kelompok tani, (3) Membuat perjanjian kerjasama antara masyarakat dengan pengelola, (4) Melakukan penyuluhan hukum, (5) Membuat tanaman baru di lahan kosong

Lima prioritas aktivitas dianggap sebagai langkah-langkah awal yang dapat dilaksanakan secara bersama oleh para pihak, tanpa tergantung pihak lain. Langkah-langkah penatakelolaan ini dirasakan sebagai proses yang paling masuk akal untuk terlaksana, karena aktor-aktor telah dapat memahami posisi masing-masing pihak. Para pihak bersepakat untuk memberi waktu selama 2 (dua) tahun bagi pencapaian langkah-langkah prioritas ini.

\section{Melakukan aksi untuk memperbaiki situasi masalah}

Pada Bulan April 2008, para pihak melakukan inventarisasi lahan Blok Agroforestri melalui pemetaan bersama. Inventarisasi lahan ditujukan untuk mengetahui status tata guna lahan areal seluas 400 hektar tersebut. Status tata guna lahan akan menunjukkan berapa luas lahan yang telah ditanami karet dan sebaran umurnya, berapa luas areal yang masih kosong, siapa saja pemanfaat yang ada berikut luas areal yang dikuasainya. Kegiatan ini merupakan batu pijakan untuk dapat melangkah ke proses kegiatan selanjutnya.

Terselenggaranya aktivitas inventarisasi lahan bersama merupakan indikator telah dimulainya langkah-langkah penatakelolaan Blok Agroforestri. Aktivitas tersebut tidak akan dapat berlangsung dalam suasana konflik. Sampai proses ini dapat disimpulkan bahwa fase intervensi Metodologi Sistem Lunak dapat mengakomodasi keragaman persepsi dan kepentingan para pihak dan terbukti menghasilkan langkah penatakelolaan bagi Blok Agroforestri Hutan Penelitian Benakat. 


\section{B. Perubahan Sikap Partisipan Penelitian}

Signifikansi perubahan sikap para pihak terjadi pada kasus pernyataan "Lahan Blok Agroforestri akan dijadikan perladangan tanaman semusim" (Tabel 4). Sikap ini cenderung negatif atau mengarah tidak akan melakukan tindakan yang menjadikan lahan sebagai perladangan tanaman semusim. Ini dimungkinkan terjadi karena dalam dalam proses penelitian terungkap bahwa tanaman semusim kurang cocok untuk lahan Blok Agroforestri dan hanya sedikit menghasilan pendapatan tunai bagi masyarakat.

Meskipun secara statistik tidak ada signifikansi perubahan sikap aktor-aktor terhadap fakta tata guna lahan saat ini (tidak berubah) namun muncul fenomena keraguan-raguan. Sebagian besar aktor menunjukkan perubahan sikapnya, tetapi terpecah pada dua kutub positif dan negatif. Ini diduga karena situasi sekarang sebenarnya merupakan zona nyaman (comfort zone) para pihak, tetapi mereka berniat untuk keluar dari situasi tersebut setelah mengikuti proses penelitian.

Tabel 4 (Table 4). Hasil analisis signifikansi perubahan sikap aktor-aktor terhadap tata guna lahan Bok Agroforestri sebelum-setelah mengikuti proses penelitian.

\begin{tabular}{|c|c|c|c|c|c|}
\hline \multirow{3}{*}{$\begin{array}{l}\text { Pernyataan } \\
\text { "Lahan di Blok Agroforestri } \\
\text { dijadikan areal..." }\end{array}$} & \multicolumn{4}{|c|}{$\begin{array}{l}\text { Hasil analisis tabel segi empat } \\
\text { terhadap elemen sikap }\end{array}$} & \multirow{3}{*}{$\begin{array}{l}\text { Signifikansi } \\
\text { Perubahan }\end{array}$} \\
\hline & A & $\mathrm{B}$ & $\mathrm{C}$ & $\mathrm{D}$ & \\
\hline & $+?-$ & $+?+$ & - ? - & $-?+$ & \\
\hline Perkebunan karet saja & 4 & 5 & 7 & 2 & Tidak nyata \\
\hline Pengembalaan ternak & 3 & 4 & 7 & 4 & Tidak nyata \\
\hline Perladangan tanaman semusim & 8 & 0 & 9 & 1 & Nyata* \\
\hline Seperti saat ini (tidak berubah) & 6 & 0 & 6 & 6 & Tidak nyata \\
\hline Hutan tanaman Acacia mangium & 3 & 0 & 10 & 5 & Tidak nyata \\
\hline $\begin{array}{l}\text { Hutan campuran karet dan pohon andalan } \\
\text { setempat }\end{array}$ & 6 & 7 & 3 & 2 & Tidak nyata \\
\hline $\begin{array}{l}\text { Hutan campuran karet, pohon andalan } \\
\text { setempat dan } A \text {. mangium }\end{array}$ & 5 & 5 & 4 & 4 & Tidak nyata \\
\hline $\begin{array}{l}\text { Tumpangsari tanaman semusim, karet, } \\
\text { dan pohon andalan setempat }\end{array}$ & 2 & 10 & 1 & 5 & Tidak nyata \\
\hline
\end{tabular}

Keterangan : ${ }^{*}$ Nyata pada taraf $\alpha=0,05$ (melalui uji binomium)

$\mathrm{A}=$ sikap positif mengarahnegatif, $\quad \mathrm{B}=$ tetap positif

$\mathrm{C}=$ tetap negatif $\quad \mathrm{D}=$ sikap negatif mengarah positif

Konsistensi sikap aktor-aktor terlihat terutama pada pilihan tata guna lahan yang sejak awal menjadi keinginan para pihak utama, yaitu lahan akan menjadi perkebunan karet, lahan akan menjadi hutan campuran karet dan pohon andalan setempat, dan lahan akan dijadikan areal tumpangsari tanaman semusim, karet dan pohon andalan setempat. Ini berarti, secara umum fase intervensi dalam proses penelitian berbasis Metodologi Sistem Lunak ini belum mampu mengubah sikap para pihak terhadap tata guna lahan Blok Agroforestri. 


\section{Pelajaran dari Proses Penelitian}

\section{Metodologi Sistem Lunak: Konflik menjadi pembelajaran sosial}

Metodologi Sistem Lunak adalah metodologi yang mengedepankan subjektifitas dan persepsi orang-orang yang terlibat dalam situasi masalah. Metodologi ini berparadigma interpretive (Sinn, 1998; Mingers, 2000; Jackson, 2001; Luckett et al., 2001), sehingga teknik penerapannya di lapangan sangat tergantung dengan konteks penelitian, situasi permasalahan, perilaku aktor-aktor, dan kemampuan pengguna.

Penelitian ini dilakukan dalam konteks intervensi terhadap kebuntuan manajemen kawasan hutan karena dianggap rawan konflik. Karenanya, pendefinisian isu menjadi awal untuk memasuki situasi masalah. Isu adalah topik penting yang akan menjadi bahan diskusi ketika kelompok yang berbeda bertemu dalam satu forum. Namun sebelum isu dapat dibatasi, pemilik isu harus ditentukan terlebih dahulu. Pemilik isu adalah pengguna dan pengelola kawasan hutan. Batasan yang dibuat oleh Rolling dan Wagemaker (1998 dalam Ramirez, 1999) ini cukup efektif membantu peneliti untuk membuka peta intervensi.

Balai Penelitian Kehutanan Palembang sebagai pengelola Blok Agroforestri, pemanfaat lahan yang berasal dari Desa Benakat Minyak dan Semangus dapat dengan baik merumuskan isu yang dikemas dalam "harapan dan masalah kami terhadap Blok Agroforestri". Stimulasi untuk merumuskan isu berasal dari informasi dari fasilitator yang diterima masing-masing kelompok tentang kondisi lapangan terkini dan posisi pihak lain.

Upaya awal untuk menggugah kepedulian komunitas pihak pengelola terhadap kawasan hutan yang dimandatkan kepadanya adalah dengan cara menyampaikan kondisi lapangan terkini (Gambar 6). Fakta lapangan terkini menjadi bahan peneliti untuk mempertanyakan pengabaian pelaksanaan tugas pokok dan fungsi pihak pengelola dan acuan bagi mereka dalam merumuskan "harapan dan masalah". Sementara, rumusan "harapan dan masalah pihak pengelola" menjadi rujukan bagi peneliti untuk menyiapkan dan merancang pertemuan dengan kelompok masyarakat. Proses ini membuka kesadaran mereka bahwa ada pihak lain yang mengancam kepentingannya. Provokasi ini berhasil mendorong para pihak utama untuk bersedia bertemu dalam satu forum untuk mendiskusikan kepentingan dan pencapaian harapan mereka.

Wawancara kelompok fokus (Focus Group Interviews-FGIs) memungkinkan peneliti untuk menggali informasi melalui pengajuan sejumlah pertanyaan kepada satu kelompok para pihak. Kelompok akan mendiskusikan jawaban kelompoknya atas pertanyaan tersebut. Ini dilakukan untuk menghindari perdebatan antara peneliti sebagai fasilitator yang berasal dari kelompok pihak pengelola (fasilitator reflektif) dengan kelompok masyarakat. Peneliti hanya memberikan pertanyaan dan menghindari membuat pernyataan. Pelajaran dari proses awal penelitian menunjukkan bahwa FGIs cukup ampuh meredam reaksi negatif kelompok masyarakat dalam pertemuan dengan aktor dari kelompok pemerintah, sekaligus menginisiasi rasa saling percaya. Patton (2002) diacu oleh Mikkelsen (2005) membuat batasan yang jelas antara diskusi dengan wawancara: wawancara kelompok fokus adalah wawancara bukan merupakan sebuah sesi pemecahan masalah sebagaimana diskusi.

Hasil observasi lapangan dan wawancara rumah tangga digunakan sebagai informasi untuk membuka cakrawala dan menunjukkan fakta objektif situasi lapangan kepada para pihak. Informasi dan fakta lapangan ini merupakan salah satu bahan refleksi ketika para pihak bertemu. Ini adalah bagian dari usaha menunjukkan kepedulian satu pihak (pengelola) terhadap pihak lainnya (masyarakat). Apresiasi terhadap apa yang telah dilakukan masyarakat ditunjukkan dengan cara mendengarkan dengan sungguh-sungguh tentang alasan-alasan masyarakat memanfaatkan Blok Agroforestri. 


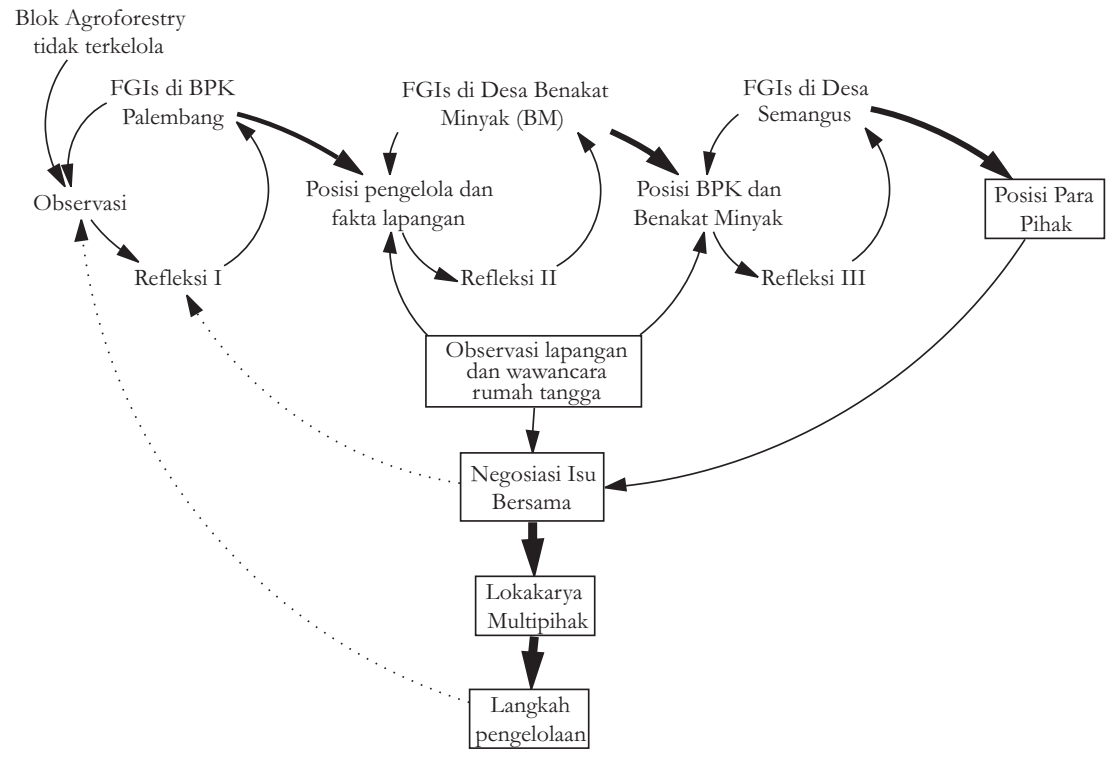

Gambar 6 (Figure 6). Strategi intervensi yang dikembangkan untuk memecahkan kebuntuan tindakan manajemen atas Blok Agroforestri Hutan Penelitian Benakat.

Metode lain untuk membangun rasa saling percaya adalah dengan menunjukkan antusiasme terhadap sesuatu yang dianggap menjadi masalah oleh aktor dari masyarakat. Selama masa penelitian di lapangan, kunjungan informal ke kediaman atau tempat kerja aktor masyarakat mampu mengurangi manifestasi dari fenomena groupthink dan menguatkan hubungan personal antara aktor-aktor masyarakat dengan peneliti. Aktor-aktor masyarakat selain pada akhirnya selalu membantu masa pra-observasi, juga berperan sebagai informan yang memantau perkembangan situasi sosial politik di lingkungan desa, dan memberi pertimbangan tentang penyesuaian waktu dan tempat yang tepat bagi pelaksanaan lokakarya.

Aktor-aktor masyarakat membuktikan bahwa mereka adalah agen perubahan di komunitasnya. Mereka umumnya adalah patron yang berperan sebagai pemimpin dalam kelompok buruh. Aktor yang ditunjuk juga merupakan tokoh yang selama ini dipercaya untuk mengurusi kepentingan umum, meskipun tidak secara formal duduk dalam struktur pemerintahan desa. Ini berarti kriteria "who really count" yang dikenalkan oleh Mitchell et al. (1997) dalam Magness (2007) dapat dimengerti oleh kelompok masyarakat Benakat dalam menentukan siapa yang mereka anggap sebagai aktor.

Kriteria keabsahan (legitimacy) dalam "who really count" diterjemahkan masyarakat sebagai orang yang memiliki jabatan dalam organisasi pemerintahan desa atau orang yang memiliki kepedulian tinggi terhadap isu. Kriteria kepentingan (urgency) diartikan masyarakat sebagai orang-orang yang mendominasi penguasaan kebun karet di areal Blok Agroforestri. Sementara kriteria kekuatan (power) melekat pada orang-orang yang memiliki kriteria keabsahan dan kepentingan. Orang-orang yang dipilih kelompok masyarakat berdasarkan tiga kriteria tersebut adalah aktor sosial di komunitasnya.

Aktor yang terlibat dalam proses penelitian ini tidak semuanya memiliki kemampuan mengkomunikasikan pengetahuannya secara efektif, meskipun terpilih karena memiliki 
kriteria "who really count". Padahal kapasitas tersebut cukup dibutuhkan dalam negosiasi dengan aktor dari pihak lain. Namun demikian, dalam konteks MSL, menurut BergvallKåreborn et al. (2004) aktor adalah orang-orang yang dapat menyebabkan terjadinya transformasi atau orang-orang yang akan melaksanakan transformasi. Karenanya, tidak semua aktor harus memiliki kapasitas sebagai negosiator, tetapi yang penting mereka memiliki komitmen yang kuat untuk melaksanakan hasil-hasil pertemuan multipihak.

Pertemuan multipihak atau lokakarya (search conference) dilaksanakan pada waktu yang disepakati bersama. Fase awal lokakarya adalah observasi masalah. Ini dimulai dengan penyampaian rumusan "sesuatu yang dianggap masalah" oleh masing-masing aktor sebagai wakil dari masyarakat maupun pihak pengelola. Selain itu, hasil observasi lapangan disampaikan juga untuk mengungkap fakta terkini. Suasana awal pertemuan masih terasa kaku, karena aktor-aktor berusaha menjaga jarak dan tidak impresif, guna menghindari terjadinya konflik terbuka.

Fasilitator menggunakan pertanyaan yang diawali dengan kata "siapa”, "apakah", dan "mengapa" untuk membantu aktor-aktor lebih memahami situasi masalah dan membangun suasana diskusi. Setiap jawaban dari satu aktor salah satu pihak dikomentari oleh aktor dari pihak lawannya. Masing-masing pihak berusaha mengajukan argumen atas "kebenaran" posisi dan tindakan mereka selama ini. Akibatnya, partisipan tidak bersedia dibatasi kebebasannya mengungkap gagasan pemikirannya, meskipun suasana diskusi cukup tegang. Situasi konflik dalam diskusi ternyata mampu menciptakan transfer informasi antarpihak. Ini adalah bentuk komunikasi baru bagi mereka, karena selama ini berusaha saling menghindari.

Terciptanya komunikasi aktif antaraktor yang berseberangan pandangan dalam hal tata guna lahan terbaik bagi kawasan hutan ini didukung oleh fasilitasi diskusi yang tidak membatasi partisipan untuk mengungkapkan pemikirannya. Fakta ini sejalan dengan teori "the ideal speech situation" dari Habermas. Menurut Habermas (1990 dalam Rist et al. 2006), Semua partisipan dalam aksi komunikatif harus dibebaskan untuk bertanya atau mengajukan usulan, mengekpresikan setiap sikap, kemauan atau kebutuhan, dan distribusi simetris kesempatan untuk berkontribusi dalam debat. Teori Habermas ini memberi perhatian khusus bagi analisis saling-hubungan antara orang-orang yang memiliki keragaman pengetahuan, misalnya antara petani (peasant) dengan peneliti (researcher) (Rist et al. 2006), sehingga terjadi intersubjective validation atas klaim kebenaran masing-masing pihak. Pembelajaran sosial menjadi fungsional pada tahap ini.

Tahapan penting MSL dalam penelitian ini adalah ketika pernyataan-pernyataan sudut pandang yang berbeda (worldview) dari para pihak utama tidak berhasil dinegosiasikan atau tidak mencapai konsensus, namun setiap pihak berkeinginan untuk menggapai harapan masing-masing. Ini terjadi karena orang-orang sulit untuk berkompromi dengan masa lalu dan kini tetapi lebih dapat saling menerima jika berbicara tentang masa depan. Teknik TW (Tranformation and Worldview---Weltanschaunng) terbukti mampu mendorong pihak-pihak yang bertentangan dalam kepentingan terhadap Blok Agroforestri untuk tetap melanjutkan proses penelitian.

Transformasi (Transformation) dan cara pandang (Worldview) merupakan elemen inti dari mnemonic CATWOE (Client Actor Transformation Worldview Ownership Enviroment), suatu teknik dalam MSL untuk mendefinisikan akar sistem (Bergvall-Kåreborn et al. 2004). Dalam konteks aplikasi MSL untuk mengelola kawasan hutan rawan konflik di Benakat ini, penggunaan TW dapat mengalihkan polarisasi posisi pihak menuju terbukanya ide-ide aktivitas untuk pencapaian tujuan masing-masing pihak. Hal ini konsisten dengan pendapat Mingers (1992 dalam Bergvall-Kåreborn et al. 2004) bahwa transformasi mampu membantu partisipan untuk memberi jarak antara dirinya dengan sistem aktual. 
Pembuatan simulasi terhadap model konseptual yang dirancang melalui MSL tidak banyak dilaksanakan oleh pengguna lain. Simulasi umumnya dilakukan dalam pemodelan kuantitatif dengan alat bantu komputasi. Penelitian ini menunjukkan bahwa interaksi aktiv antar orang-orang yang memiliki kepentingan berbeda tetap dapat menghasilkan dialog proyeksi situasi masa depan, melalui pelajaran pengalaman masa lalu, fakta saat ini dan bantuan model konseptual. Simulasi juga berhasil mendorong aktor-aktor untuk mengungkap fakta sebenarnya atas situasi dan kondisi areal Blok Agroforestri. Simulasi identik dengan pemanfaatan fakta dan data kuantitatif, sehingga hasilnya bergantung dengan "kejujuran" atas data dan fakta itu sendiri. Karenanya, simulasi seperti ini dapat dipertimbangkan untuk menjadi metode kualitatif utama dalam rancangan penelitian sosial konstruktif atau kritis.

Pemodelan dalam MSL ini merupakan proses adaptif, karena terjadi umpan balik antara proses memodelkan dengan hasil ekspresi situasi masalah. Jadi, meskipun pada situasi sebenarnya tidak terbangun hubungan yang positif di antara para pihak utama, namun terjadi dalam dunia sistem (model konseptual). Perbandingan antara aktivitas di dunia sistem dengan situasi sebenarnya ternyata mampu mendorong para pihak untuk mengubah situasi konflik menjadi komitmen interaksi positif dalam masa depan, demi kepentingan pencapaian harapan masing-masing pihak.

Perbedaan preferensi terhadap tata guna lahan Blok Agroforestri dianggap sebagai akar terjadinya konflik antara masyarakat dengan pihak kehutanan. Perubahan sikap aktoraktor terhadap tata guna lahan Blok Agroforestri yang mereka inginkan belum terjadi secara siginifikan dalam fase intervensi aplikasi MSL ini. Sikap para pihak terhadap tata guna lahan terbaik bagi Blok Agroforestri bisa jadi akan berubah apabila mereka dapat mempertahankan aksi komunikatif dalam menjalankan komitmen kesepakatan skenario pengelolaan Blok Agroforestri. Ini dimungkinkan terjadi karena proses pembelajaran dalam MSL masih akan terus berlangsung. Namun demikian, dalam proses penelitian telah terjadi perubahan sikap aktor-aktor terhadap hubungan diantara mereka dan terhadap aktivitas yang selama ini masing-masing pihak lakukan.

Rencana aksi yang dihasilkan dalam proses penelitian ini disepakati secara spontan untuk dikuatkan dalam bentuk rumusan bersama dan ditandatangani oleh semua aktor yang terlibat dalam lokakarya. Secara spontan pula, wakil aktor dari Desa Benakat Minyak menyampaikan pidato apresiasinya terhadap proses penelitian, seperti berikut ini:

\section{Kami terkesan dengan apa yang dilakukan oleb beberapa orang muda dari Palembang ini yang sejak awal berupaya agar apa yang selama ini dikelubkan masyarakat dan mungkin juga menjadi ganjalan hubungan kita selama ini menjadi cair. Sekarang telah jelas apa yang kami harapkan Bapak-bapak sudah tabu dan apo yang Bapak-bapak pikirkan juga kami sudah mengerti. Insya Allah kami sebagai tokoh masyarakat akan sama-sama saling mendukung bagaimana caranya apa yang telah kita hasilkan hari ini terwujud. Jadi tolong hubungan baik kita ini kita pertahankan, supaya tidak ada lagi saling curiga (Bapak. Haris, tokoh masyarakat Desa Benakat Minyak.)}

Secara ringkas, pelajaran utama dari aplikasi metodologi sistem dalam konteks upaya "pengelolaan kembali" kawasan hutan yang rawan konflik adalah bahwa kinerja pengelolaan sumberdaya yang dilihat dan dirasakan (phenomena) saat ini adalah hasil (konstruksi) dari keragaman cara pandang, sistem nilai, dan pengetahuan orang-orang yang terlibat dalam situasi masalah. Karenanya, upaya untuk memperbaiki kinerja tersebut adalah dengan cara 
membongkar (dekonstruksi) cara pandang, sistem nilai, dan pengetahuan mereka kemudian merangkai kembali (rekonstruksi) dengan cara pandang, sistem nilai, dan pengetahuan baru. Proses ini dimungkinkan terjadi dengan cara-cara lunak (soft). Cara lunak mengedepankan penghargaan terhadap keragaman perspektif, sehingga terjadi validasi klaim "kebenaran" antarpihak. Validasi menyebabkan pertukaran informasi yang dapat mengarahkan terjadinya umpan balik informasi. Umpan balik informasi yang mempengaruhi keputusan-keputusan berikutnya dari pihak-pihak adalah penyebab terjadinya perubahan. Pengelolaan kembali kawasan hutan "tidak terkelola" adalah wujud dari proses menuju perubahan tersebut.

\section{Penyesuaian kerangkakerja MSL: sebuah umpan balik}

Kerangkakerja MSL terbukti handal dalam menciptakan tindakan menuju perubahan situasi permasalahan pada banyak bidang kajian, termasuk dalam penelitian ini. Namun demikian, beberapa fitur keunggulan pendekatan MSL ini tetap menyisakan kelemahan dan berpotensi menutupi manfaat (outcomes) yang dihasilkan.

Perubahan sistem yang diidentifikasi oleh proses MSL dalam penelitian ini cenderung bersifat "revolusioner" atau mendadak. Sebelum dilaksanakannya pertemuan multipihak pada Bulan November 2007, para pihak utama tidak memilliki struktur dan prosedur hubungan kerja sama sekali. Komitmen untuk segera mewujudkan agenda aksi bersama pada Bulan Desember 2007 terkendala oleh kegamangan pihak Balai Penelitian Kehutanan dalam menyesuaikan rencana kegiatan tersebut dengan agenda rutin institusinya. Pada kenyataannya, terjadi tarik menarik kepentingan antara aktor-aktor yang terlibat dalam proses penelitian aksi dengan individu-individu lain di komunitasnya. Ini menyebabkan terjadinya pengunduran jadwal implementasi rencana aksi. Siapa yang bertanggung jawab untuk mengadaptasikan agenda aksi ke dalam hirarki subsistem yang lebih tinggi (komunitas) merupakan masalah yang tidak diantisipasi oleh kerangkakerja MSL.

Basis kerangkakerja MSL adalah menyandarkan proses "memodelkan" dan perdebatan model dengan dunia nyata pada nilai-nilai dan keyakinan aktor-aktor. Padahal nilai-nilai dan keyakinan aktor-aktor pada dasarnya dibentuk oleh struktur sistem yang lebih luas dan kompleks. Ini menyebabkan munculnya potensi resistensi dan keraguan individuindividu lain yang tidak terlibat dalam proses penelitian terhadap agenda aksi. Menurut peneliti, potensi resistensi dapat diatasi melalui 2 (dua) cara, yaitu: (1) Dalam tahap pemahaman situasi masalah (tahap 1); sepakati situasi masalah yang dianggap "tidak bisa diintervensi" (given), kemudian keluarkan isu tersebut dalam proses tahapan lebih lanjut, (2) Dalam tahap menetapkan rencana aksi (tahap 6); pertimbangkan untuk memasukkan aktivitas "sosialisasi rencana aksi" pada struktur hirarki subsistem yang lebih tinggi sebagai langkah awal dalam agenda rencana aksi.

Keraguan orang-orang yang tidak terlibat langsung dalam proses penelitian berbasis MSL merupakan sesuatu yang wajar, namun jika tidak diantisipasi sejak dini dapat menyebabkan terhentinya proses implementasi rencana aksi. Ini terjadi karena kerangkakerja MSL hanya didasarkan pada penafsiran aktor-aktor yang terlibat dalam proses penelitian. Aktor-aktor tidak menyadari dampak nyata (outcome) dari perubahan yang diinginkan. Apabila perubahan tersebut merupakan peubah pendorong terjadinya perubahan perilaku sistem secara keseluruhan, maka keraguan terhadap proses MSL akan semakin beralasan. Keraguan itu dapat diatasi melalui penggabungan antara MSL dengan metodologi lainnya, seperti aplikasi simulasi dalam penelitian ini.

Penggabungan antara MSL dengan metodologi lainnya, terutama Metodologi Sistem Keras (Hard Systems Methodology-MSK), misalnya Dinamika Sistem, Simulasi Multi Agen, 
adalah upaya menguatkan proses dan manfaat penelitian aksi. MSL menghasilkan pemahaman situasi masalah secara menyeluruh, sementara MSK bermanfaat dalam membandingkan antara model konseptual dengan dunia nyata (Gambar 7).

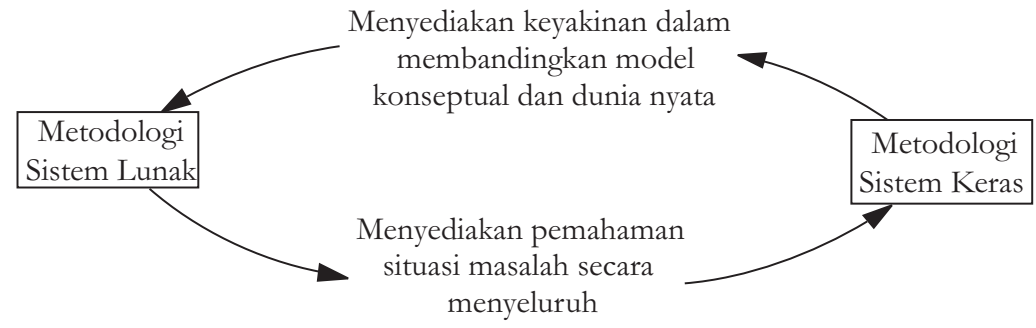

Gambar 7 (Figure 7). Metodologi Sistem Lunak dikuatkan oleh Metodologi Sistem Keras.

Rencana aksi yang dihasilkan oleh proses MSL merupakan komitmen aktor-aktor untuk memperbaiki situasi masalah. Sayangnya, kerangkakerja MSL tidak menyediakan langkah kerja yang memungkinkan pemantauan (monitoring) pelaksanaan rencana aksi pada fase implementasi. Ini dapat menyebabkan ketidakberlanjutan proses pembelajaran antarpihak. Agenda aksi dapat saja dianggap sebagai aktivitas rutin bagi masing-masing pihak. Jika demikian maka implementasi aksi berpotensi memunculkan masalah baru, seperti memperburuk hubungan antarpihak dan menjauhkan pencapaian sasaran-sasaran masingmasing terhadap sumberdaya yang ingin dikelola.

Kelemahan aspek pemantauan implementasi rencana aksi dalam kerangkakerja MSL telah cukup sering didiskusikan oleh pakar-pakar analisis sistem. Champion dan Stowell (2003) dan Champion (2007) mengusulkan penggunaan kerangkakerja PEArL sebagai pengarah (guidance) implementasi agenda aksi. Mnemonic PEArL adalah Participants, Engagement, Authority, relationship, dan Learning. Menurut mereka kerangkakerja ini akan meningkatkan validitas pelaksanaan penelitian aksi terhadap manfaat akhir (final outcomes) yang diinginkan. Setiap elemen (langkah) pelaksanaan agenda aksi diminta untuk mempertimbangkan kerangkakerja PEArL sebagai penilai apakah proses yang dilakukan tetap dalam koridor nilainilai dasar penelitian aksi.

\section{Peran fasilitasi reflektif}

Metodologi Sistem Lunak tidak memiliki prosedur yang bersifat mekanistik, namun hanya memuat prinsip-prinsip untuk melakukan analisis sistem dan pemodelan berdasarkan perspektif orang-orang yang terlibat dalam situasi masalah yang dihadapi. Oleh karena itu, media pelaksanaannya dapat saja beragam, tergantung konteks dimana metodologi ini digunakan. Dalam kasus upaya manajemen kawasan hutan yang rawan konflik, fasilitasi merupakan media yang tepat untuk mengawal proses penelitian. Menurut Standa-Gunda et al. (2003) kombinasi pemodelan dan partisipasi dapat menciptakan lingkungan yang kondusif bagi pembelajaran sosial, namun ini hanya dapat dicapai melalui fasilitasi yang baik. Aplikasi MSL di Benakat ini dilakukan melalui fasilitasi reflektif.

Fasilitasi reflektif adalah metode fasilitasi yang dilakukan oleh salah seorang atau sekelompok orang yang berperan pula sebagai aktor dalam proses, melalui pelibatan praktik pemikiran sistem (Groot dan Maarleveld 2000). Ini didasarkan pada kepentingan untuk membangun komunikasi antarpihak, dimana interaksi antaraktor pada pihak yang berbeda 
diwarnai dengan stereotif dan prasangka. Selener (1997) menyebutnya sebagai gaya fasilitasi dari dalam proses. Dalam penelitian ini, fasilitasi reflektif terbukti mampu membuka jalur komunikasi para pihak utama untuk bersedia mendiskusikan masa depan Blok Agroforestri (Gambar 6).

Bukti keberhasilan fasilitasi reflektif ini dapat membuka wacana baru tentang peran ideal aparat pemerintah, khususnya dalam pengelolaan sumberdaya alam dan lingkungan. Hemmati (2002: 222) menyebutkan bahwa proses dialog antarpihak secara ideal difasilitasi oleh orang yang bukan merupakan para pihak dan tidak mempunyai kepentingan langsung dari manfaat proses. Namun, dalam kasus ini, dimana pengelola 'mengabaikan' pengelolaan kawasan hutan yang dimandatkan kepadanya dan masyarakat tidak memperoleh kepastian tentang status "pengusahaannya" maka fasilitasi reflektif adalah pendekatan yang paling mungkin. Kreativitas diyakini tidak akan muncul dalam suasana diam dan stabil. Suatu kelompok akan kreatif apabila menjalani proses yang memungkinkan terjadinya benturan pemikiran dan kepentingan kemudian dapat mengakomodasinya, sebagaimana dilakukan dalam proses MSL (Molineux dan Haslett 2007). Fasilitasi ini bersifat inisiatif dan upaya kritis untuk keluar dari situasi yang dianggap nyaman oleh kelompok fasilitator.

Posisi sebagai insider memungkinkan fasilitator untuk tidak kaku dalam menggunakan metode-metode kualitatif dan mengakui keragaman perspektif serta meluaskan partisipasi. Fasilitator reflektif mendorong terjadinya refleksi kritis dan saling menilai, membangun interaksi yang lebih intim serta merangsang semua aktor yang terlibat dalam proses untuk berperan sebagai fasilitator pula. Pada fase diskusi penyusunan model konseptual hingga disepakatinya rencana aksi bersama, peran peneliti sebagai fasilitator menjadi pasif, karena aktor-aktor lain secara tidak sadar telah bertindak sebagai fasilitator.

\section{Implikasi Kebijakan}

Konflik dalam pengelolaan sumberdaya kawasan hutan merupakan fakta tidak terhindarkan. Pengelola lazimnya mengetahui kerumitan situasi dan kondisi kawasan hutan yang dimandatkan kepadanya dari hasil observasi masalah. Ironisnya, keruwetan tersebut makin diperparah dengan ketidakmampuan menyusun rencana tindakan manajemen yang adaptif. Sehingga, seringkali rencana tindakan manajemen harus diperbaharui setiap tahun untuk mengikuti dinamika sosial politik.

Analisis sistem dan pemodelan kualitatif yang berorientasi aksi sebagaimana dicontohkan dalam penelitian ini, dapat digunakan untuk merefleksi hasil-hasil observasi masalah. Refleksi akan membawa pencapaian konsep perencanaan aksi (action planning). Konsep perencanaan seperti ini menjadi lebih adaptif, dalam arti akan mampu menyesuaikan dengan perubahan yang terjadi. Oleh karena itu, pengelola-pengelola kawasan hutan tidak perlu setiap tahun melakukan observasi masalah, sehingga terkesan melakukan pemborosan dan tidak berani bertindak apapun. Setiap tindakan manajemen diobservasi kembali manfaat dan dampaknya, kemudian secara iteratif berlanjut lagi pada proses pembelajaran berikutnya.

Intervensi terhadap situasi masalah yang rumit tidak harus melibatkan pihak luar. Fasilitasi reflektif dalam penelitian ini terbukti mampu memecahkan kebekuan komunikasi antar pihak yang berseberangan perspektif dan kepentingan. Pihak pengelola kawasan hutan "tidak terkelola" seharusnya dapat memanfaatkan stafnya sendiri untuk melakukan intervensi melalui fasilitasi. Pemerintah harus mulai bergeser dari cara rutin berpikir yang menganggap dirinya sebagai pelaksana kegiatan saja, menjadi fasilitator proses manajemen bagi kawasan hutannya. 
Fasilitator reflektif dapat diperankan oleh semua aktor dari pemerintah maupun masyarakat lokal. Hasil penelitian Kolfschoten et al. (2007) menunjukkan bahwa kinerja dan penggunaan informasi oleh fasilitator baru tidak sangat berbeda dengan fasilitator pada tingkat ahli, namun mereka (fasilitator baru) kurang fleksibel karena pengalamannya masih terbatas. Ini berarti, pihak pengelola kawasan hutan tidak perlu repot mengundang atau menunggu datangnya fasilitator handal untuk memulai intervensi, tetapi cukup memanfaatkan orang-orang mereka sendiri.

\section{KESIMPULAN DAN SARAN}

\section{A. Kesimpulan}

1. Prinsip-prinsip Metodologi Sistem Lunak yang dijalankan melalui strategi fasilitasi reflektif mampu mengubah suasana konflik yang disebabkan oleh perbedaan perspektif dan kepentingan menjadi media pembelajaran sosial saling memahami, sehingga menghasilkan langkah penatakelolaan bagi Blok Agroforestri Hutan Penelitian Benakat yang semula "tidak terkelola".

2. Fase intervensi dalam tahapan Metodologi Sistem Lunak ini belum secara signifikan mengubah sikap para pihak terhadap preferensi tata guna lahan. Ini berarti potensi konflik dalam masa depan tetap ada, namun berpeluang untuk dikelola setelah terbukanya jalur komunikasi antarpihak melalui beragam aktivitas pengelolaan bersama.

\section{B. Saran}

1. Model konseptual sebagai representasi hubungan beragam aktivitas bertujuan dalam masa depan dapat dijadikan pedoman interaksi para pihak pada saat melaksanakan aksi menuju perubahan situasi masalah. Resolusi konflik dapat berwujud perbaikan kembali model konseptual yang ada sebagai refleksi sistem aktivitas yang lebih diinginkan.

2. Metodologi Sistem Lunak dapat dijadikan alternatif pendekatan untuk mengintervensi kawasan-kawasan hutan yang dianggap rawan konflik di Indonesia. Aplikasi metodologi ini dalam konteks upaya penatakelolaan kawasan hutan yang lebih kompleks (isu lebih luas, para pihak lebih banyak) sebaiknya dikombinasikan dengan metodologi lainnya.

\section{DAFTAR PUSTAKA}

Abbas, R. 2005. Mekanisme perencanaan partisipasi stakeholder Taman Nasional Gunung Rinjani [Disertasi]. Bogor: Sekolah Pascasarjana Institut Pertanian Bogor.

Adelson, B. 1999. Developing strategic alliances: A framework for collaborative negotiation in design. Research in Engineering Design, 11:133-144.

Bervall-Kareborn B., A. Mirijamdotter, and A. Basden. 2003. Basic principles of SSM modelling: An examination of CATWOE from a soft perspective. Systemic Practice and Action Research, Vol. 17. No.2: 55-73. 
Brits H., and L. du Plessis. 2007. Application of focus group interviews for quality management: An action research project. Systemic Practice and Action Research 20:117126.

Bunch, M.J. 2003. Soft systems methodology and the ecosystem approach: A system study of the cooum river and environs in Chennai, India. Enviromental Management, Vol. 31, No. 2, pp. 182-197.

Champion, D and F.A. Stowell. 2003. Validating action research field studies: PEArL. Systemic Practice and Action Research, 16(1):21-36.

Champion, D. 2007. Managing action research: the PEArL framework. Systemic Practice and Action Research. In Press.

Chapman, J. 2004. System Failure: Why governments must learn to think differently. London: Demos.

Eriyatno. 2003. Ilmu Sistem:Meningkatkan Mutu dan Efektivitas Manajemen. Bogor: IPB Press.

Eriyatno dan F. Sofyar. 2007. Riset Kebijakan: Metode Penelitian untuk Pascasarjana. Bogor: IPB Press.

Groot, A. dan M. Maarleveld. 2000. Demystifying Facilitation in Participatory Development. London: Gatekeeper Series no.89. IIED.

Haklay, M. 1999. Soft systems methodology analysis for scoping in environmental impact statement in Israel. CASA University College London. http://www.casa.ucl.ac.uk/publications/workingPaperDetail.asp?ID=13. Diakses tanggal 27 Pebruari 2007.

Holwell, S. 2000. Soft systems methodology: Other voices. Systemic Practice and Action Research, Vol. 13, No. 6: 773-797.

Jackson, M.C. 2001. Critical systems thinking and practice. European Journal of Operational Research, 128:233-244.

Kadir, A. 2005. Pengembangan sosial forestry di SPUC Borisallo; Analisis sosial ekonomi dan budaya masyarakat. Info Sosial Ekonomi, Vol. 5 No. 3.

Kolfschoten, G.L., M.D. Hengst-Bruggeling, and G.J. De Vreede. 2007. Issues in the design of facilitated collaboration processes. Group Decision and Negotiation, 16:347-361.

Luckett, S., S. Ngubane, and B. Memela. 2001. Desigining a management system for rural community development organization using a systemic action research process. Journal of Systemic Practice and Action Research, Vol. 14, No.4:517 542.

Magness, V. 2007. Who are the stakeholder now? An empirical examination of the Mitchell, Agle, and Wood theory of stakeholder salience. Journal of Business Ethics 2007.

Malik I, B. Wijardjo, N. Fauzi, dan A. Royo. 2003. Menyeimbangkan Kekuatan: Pilihan Strategi Menyelesaikan Konflik atas Sumber Daya Alam. Pellokila, Y.Y.K., Prasetyohadi, D. Trisasongko, penyunting. Jakarta: Yayasan Kemala.

Martins, H. and J.G. Borges. 2007. Addressing collaborative planning methods and tools in forest management. Forest Ecology and Management. In Press.

Penatakelolaan Kawasan Hutan Rawan Konflik Melalui Pendekatan

(Edwin Martin et all.) 
McNiff, J. 1992. Action Research: Principles and Practice. London: Routledge.

Mikkelsen, B. 2005. Methods for Development Work and Research. A New Guide for Practitioners, Second Edition. London: Sage Publications.

Mingers, J. 2000. An idea ahead of its time: The history and development of soft systems methodology. Systemic Practice and Action Research, Vol. 13, No.16:733-751.

Nidumolu, U.B., C.A.J.M. de Bie, H. van Keulen, A.K. Skidmore, and K. Harmsen. 2006. Review of land use planning programme through the soft systems methodology. Land Use Policy 23: 187-203.

Rámirez, R. 1999. Stakeholder analysis and conflict management. In Buckles, D, editor. Cultivating Peace : Conflict and Collaboration in Natural Resource Management. New York: IDRC/World Bank.

Rámirez, R. and M. Fernándes. 2005. Facilitation of collaborative management: Reflection from practice. Systemic Practice and Action Research, Vol. 18 No.1.

Rist, S., M. Chiddambaranathan, C. Escobar, and U. Wiesmann. 2006. "It was Hard to Come to Mutual Understanding..."The Multidimensionality of social learning processes concerned with sustainable natural resource in India, Africa and Latin Amerika. Systemic Practice and Action Research, 19:219-237.

Siegel, S. 1992. Statistik Nonparametrik untuk Ilmu-Imu Sosial. Jakarta: PT Gramedia Pustaka Utama.

Simonsen, J. 1994. Soft systems methodology. An introduction. Roskilde University. www.jespersimonsen.dk/Downloads/SSM-IntroductionJS. Diakses pada tanggal 27 Pebruari 2007.

Sinn, J.S. 1998. A comparison of interactive planning and soft systems methodology: Enhancing the complementarist position. Systemic Practice and Action Research, Vol. 11 No. 4: 435-453.

Suharti, S., T. Rostiwati, N. Mindawati. 2005. Pola kolaboratif dalam pengelolaan kawasan hutan dengan tujuan khusus (KHDTK) Haurbentes. Jurnal Penelitian Hutan dan Konservasi Alam Vol. II No. 5 :527-537.

Wiati, C.B. 2005. Apakah setelah desentralisasi hutan penelitian lebih bermanfaat untuk masyarakat lokal. CIFOR Governance Brief No 13.

Williams, B. 2005. Soft systems methodology. The Kellogg Foundation. users.actrix.co.nz/bobwill/ssm. Diakses pada tanggal 4 Pebruari 2007.

Williamson, O.E. 1996. The Mechanism of Governance. New York, USA: Oxford University Press.

Zubair M, C. Garforth. 2006. Farm level tree planting in Pakistan: the role of farmers' perceptions and attitudes. Agroforestry Systems, 66:217-229. 